\title{
ARTICLES
}

\section{Trans-Pacific Partnership and the Multilateralization of International Investment Law}

\section{Congyan Cai*}

The multilateralization of international investment law has witnessed repeated disappointments over the past six decades. Current negotiations regarding the Investment Chapter within the Trans-Pacific Partnership Agreement may bring about a new promise for this process. It is necessary for the TPP negotiating parties to have a proper understanding of this recent history. Circumstances under which the TPP negotiations are conducted are quite different from those of the past. Thus, it can be assumed that TPP negotiations will be concluded successfully and may have profound implications on the multilateralization of international investment law. Since TPP negotiations have multilateral consequences, several new initiatives have been proposed amongst the TPP negotiating parties, which may help alleviate the 'legitimacy crisis' of the past two decades. These initiatives include a new principle of Special and Differential treatment, operative provisions on investment promotion, a Side Agreement on code of conduct of transnational corporations, and an appellate mechanism for reviewing arbitral awards.

\section{Keywords}

Trans-Pacific Partnership, International Investment Law, Multilateralization, P4 Agreement, BITs, MAI

* Professor of International Law at Xiamen University, China. B.A., LL.M., Ph.D. (Xiamen) This paper is the fully revised version of the author's presentation titled, "Trans-Pacific Strategic Economic Partnership Agreement: Issues and Prospects" sponsored by Law Research Institute at the University of Seoul and Korea Branch of the International Law Association on October 26, 2012. Much gratitude should be extended to participants for their comments and discussions. This research is also supported by China's Ministry of Education through the Program for New Century Excellent Talents in University and by Xiamen University through the Fundamental Research Funds for the Central Universities. The author may be contacted at: caicongyan@xmu.edu.cn / Address: Faculty of Law, Xiamen University, Xiamen City, Fujian Province 361005 China. 


\section{Introduction}

The General Agreement on Tariffs and Trade ("GATT") was created more than 60 years ago to establish a multilateral framework to govern international trade. To date, no such multilateral framework exists vis-a-vis transnational investment. ${ }^{1}$ As such, the prevailing approach revolves around bilateral trade agreements. Nevertheless, efforts to multilateralize investment rules continue to develop. The Trans-Pacific Partnership ("TPP”) negotiations may be one such effort that would successfully multilateralize international investment rules. ${ }^{2}$

The idea of the TPP originated from the negotiations for the Pacific Three Closer Economic Partnership (hereinafter P3 Agreement) among Chile, New Zealand and Singapore. It was convened in 2002 and joined by Brunei Darussalam in 2005. Then, these four States signed the Trans-Pacific Strategic Economic Partnership Agreement (hereinafter P4 Agreement), which came into force in 2006. ${ }^{3}$ According to the provision of open accession of the P4 Agreement, ${ }^{4}$ the United States (2008), Australia (2008), Peru (2008), Vietnam (2008), Malaysia (2010), Mexico (2012) and Canada (2012) have joined in negotiations towards signing a TPP Agreement. ${ }^{5}$

The P4 Agreement itself does not include an Investment Chapter. However, it provides that "negotiations on investment regime shall start no later than two years after entry into force of that Agreement." ${ }^{6}$ On June 12, 2012, the negotiated text of the Investment Chapter was released. ${ }^{7}$

This paper analyzes the effect the TPP Investment Chapter negotiations may have on the multilateralization of international investment law. It is divided into five parts including an Introduction and Conclusion. Part two will begin with some theoretical debates regarding multilateralization. Part three will trace several

1 J. Morin \& G. Gagné, What Can Best Explain the Prevalence of Bilateralism in the Investment Regime?, 36 InT'L J. PoL. ECON. 53 (2007).

2 R. Dattu, A Journey from Havana to Paris: the Fifty-Year Quest for the Elusive Multilateral Agreement on Investment, 24 FordHAM INT'L L.J. 275 (2000).

3 See Trans-Pacific Strategic Economic Partnership Agreement, available at http://www.mfat.govt.nz/downloads/tradeagreement/transpacific/main-agreement.pdf (last visited on Sep. 9, 2013). For details, see M. Lewis, Expanding the P-4 Trade Agreement into a Broader Trans-Pacific Partnership: Implications, Risks and Opportunities, 4 AsIAN J. WTO \& InT'L Health L. \& Pol'y 401(2009).

4 P4 Agreement art. 20.6.

5 See Trans-Pacific Partnership Negotiations History, available at http://www.mfat.govt.nz/Trade-and-EconomicRelations/2-Trade-Relationships-and-Agreements/Trans-Pacific/index.php\#history (last visited on Sep. 9, 2013).

6 P4 Agreement art. 20.1.

7 See Investment Chapter (leaked) of TPP negotiations, available at http://www.citizenstrade.org/ctc/wp-content/ uploads/2012/06/tppinvestment.pdf (last visited on Sep. 1, 2013). 
attempts towards multilateral investment regimes over the past six decades. These two parts attempt to provide the theoretical foundation and empirical background for the current TPP negotiations. Part four will analyze the potential implications the TPP negotiations may have on the multilateralization of international investment law. It will firstly provide a general evaluation of such implications followed by an examination on negotiation strategies being employed by the parties. Furthermroe, it will propose several new initiatives to improve the TPP investment regime and, as such, contribute to the multilateralization of investment governance.

\title{
II. Multilateralization of International Investment Law: Some Theoretical Debates
}

\begin{abstract}
A. Features
Multilateralization, in this article, may be defined as a "process moving towards a multilateral institution." International relations scholars would describe it as 'multilateralism' having the following three indivisible features: (1) indivisibility; (2) generalized principles of conduct; and (3) diffuse reciprocity. ${ }^{8}$ The 'indivisibility' means "the scope (both geographic and functional) over which costs and benefits are spread, given an action initiated in or among component units" of multilateral institutions ${ }^{9}$ The "generalized principles of conduct" means that the multilateralization "generally come[s] in the form of norms exhorting general if not universal modes of relating to others, rather than differentiating relations caseby-case on the basis of individual preferences, situational exigencies, or a priori particularistic grounds. ${ }^{10}$ Ruggie stressed that multilateralism is "without regard to the particularistic interest of the parties or the strategic exigencies that may exist in any specific occurrence." ${ }^{11}$ The underlying rationale hence is to provide a level playing field for all participants. The 'diffuse reciprocity' aims at providing comforts to the States that they can be "benefit[ed] in the long run and over many issues, rather than every time on every issue"12 and that these benefits are of "rough

8 J. Ruggie, Multilateralism: The Anatomy of an Institution, in Multilateralism Matters: The Theory and Praxis of an Institutional Form 3-48 (J. Ruggie ed., 1993).

9 J. Caporaso, International Relations Theory and Multilateralism, in Ruggie, supra note 8, at 53-54.

10 Id.

11 Supra note 8, at 11.

12 Supra note 9, at 54.
\end{abstract}


equivalence. ${ }^{13}$ It implies that some States may avail less benefits or lose more than others in a specific period and/or over a given issue.

However, this simplified description does not fully reflect the reality. In practice, multilateral institutions do not disregard "individual preferences, situational exigencies, or a priori particularistic grounds." Rather, they often accommodate diversity among participants through permitting special arrangements for some States, especially developing countries. The GATT/WTO, a recognized successful multilateral institution, is a case in point. While the GATT/WTO provides for Most-favored-Nation ("MFN") treatment, "generalized principles of conduct" from a viewpoint of international relations, ${ }^{14}$ it allows many arrangements tailored to particular circumstances for some parties. Under the General Agreement on Trade in Services (“GATS”), e.g., different WTO members undertake divergent obligations of liberalization in trade in services, depending on their commitments made in "Schedules of Specific Commitments."

\section{B. Benefits and Costs}

\section{Benefits}

Several benefits have been suggested to argue for multilateralism. The first one is transaction costs advantage. Some writers contend that if activities undertaken between each pair of States are substantially the same, "large gains may be expected through multilateral organization." ${ }^{16}$ This advantage was defined as "political economies of scale." ${ }^{\text {17 }}$ Ruggie observed that one important reason for turning to multilateral institutions is cost, "because to organize them differently would be more costly." ${ }^{18}$ In terms of investment treaties, the United Nations Conference for Trade and Development ("UNCTAD") predicted that if international investment would be totally regulated by bilateral investment treaties ("BITs"), a network with more than 18,000 treaties of this kind is needed, ${ }^{19}$ which is indeed very difficult, if not impossible, to be achieved. However, the benefit of transaction cost should not been overestimated because it would be traded off by the spread of costs arising from the indivisibility of mutlilaterism.

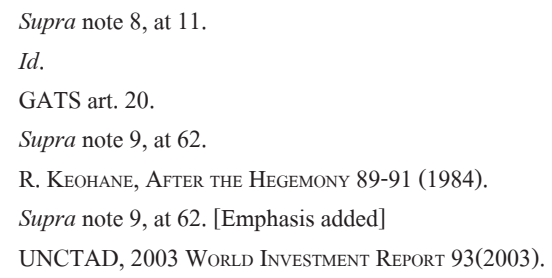


The second benefit is to alleviate the "fragmentation of governance." The fragmentation has been recognized as an important concern of international law. ${ }^{20}$ As for investment treaties, a similar concern has also been raised since in some investment disputes the same provisions were inconsistently interpreted under identical or similar circumstances. This phenomenon contributes to the 'legitimacy crisis' of investment treaties. ${ }^{21}$ The coherence and certainty are fundamental to any body of law including international law. However, all laws are based on diverse social background. The more dynamic social circumstances and individual situations are, therefore, the more flexible law tends to be. The United Nations International Law Commission ("ILC") evaluated the "fragmentation of international law" in a neutral manner as having "both positive and negative sides." 22 While often creating conflicting institutional practices, it reflects "the rapid expansion of international legal activity into various new fields and the diversification of its objects and techniques." ${ }^{23}$ Alvarez rightly warned the hazards of 'premature de-fragmentation' in international investment law. ${ }^{24}$

The third benefit is 'democracy.' Multilateralism is arguably "an alternative concept to a hegemonic order that is characterized by rules that unilaterally favor the hegemon's self-interest without placing other participating actors on an equal footing. ${ }^{25}$ This argument seems appealing, especially for non-hegemonic States who have long been criticizing the 'democratic deficit' in international law. As a general rule, the more States that are involved in multilateral negotiations will dilute the hegemonic political power of the few. However, more states does not necessarily bring about better results, as more self-interests often correlate to less efficient lawmaking. Moreover, multilateral institutions might be a more favorable forum for the hegemonic competition between great powers than bilateral forum. ${ }^{26}$

Because the above-mentioned benefits are not always reliable, it is necessary to find a way how they come into reality in practice. For example, it is obvious that the benefit of diffuse reciprocity is prospective in nature. Several contingent factors

20 See generally Fragmentation of International Law: Difficulties Arising from the Diversification and Expansion of International Law: Report of the Study Group of the International Law Commission, U.N. Doc. A/CN.4/L.682 (Apr. 13, 2006), available at http://untreaty.un.org/ilc/documentation/english/a_cn4_1682.pdf (last visited on Sept. 9, 2013).

21 S. Frank, The Legitimacy Crisis in Investment Treaty Arbitration: Privatizing Public International Law through Inconsistent Decisions, 73 Fordham L. Rev. 1521(2005).

22 Supra note $20, \uparrow 14$.

23 Id.

24 J. Alavrez, The Public International Law Regime Governing International Investment 405(2011).

25 S. Schill, The Multilateralization of International Investment 10 (2010).

26 J. Alavrez, Intermational Organizations as Law-Makers 199-216 (2005). 
would, however, determine whether, to what extent, and when it can be realized. They include: (1) whether a State is capable of pursuing the benefit; (2) whether the beneficiary States are more inclined to act in good faith to enhance diffuse reciprocity; and (3) whether effective mechanisms are designed in multilateral institutions to enhance diffuse reciprocity. With regard to an investment treaty regime, Salacause and Sullivan recognized that BITs were entrusted with the following three goals: (1) investment protection; (2) market liberalization; and (3) investment promotion. ${ }^{27}$ For developing countries, there is no conclusive evidence that BITs can significantly promote capital flow to their markets, ${ }^{28}$ which is the foremost benefit for them. As for investment protection, BITs are quite effective. ${ }^{29}$ As far as developing countries are concerned, this benefit may be important as 'host' States because it enhances the confidence of foreign investors. ${ }^{30}$ However, this benefit is of little significance as 'home' States since few developing States are important investment destinations. Although Salacause and Sullivan's research is based on BITs, their finding also applies to multilateral investment regime.

\section{Costs}

Turning to the costs of multilateralism, it suffices to examine the indivisibility of multilateral institutions. As mentioned above, once a State makes commitments within a multilateral institution, it has to fulfill obligations towards every other member of that institution. In addition, States that claim to honor commitments may increase over time as multilateral institutions may expand their members. In this case, commitments would be more dynamic and demanding over time. Let's take a look at the GATT: When a State made commitments to liberalize its trade regime in 1947, it should have recognized that its commitments would be applied to more than the 20 founding members. There were few who could have predict such a dramatic expansion of 20 original GATT States in 1947 to the over 157 current WTO Members, ${ }^{31}$ as well as substantive expansion including trade in services, investment, and intellectual property.

In modern democratic society, potential costs would often have more influence than potential benefits on constituents' attitudes toward public policymaking.

27 J. Salacause \& N. Sullivan, Do BITs Really Work?, 46 Harv. Int'L L. J. 67 (2005).

28 Id. at $95-111$.

29 Id. at 90.

30 See Amco v. Indon., Decision on Jurisdiction, Sept. 25, 1983, 1 ICSID Reports 1993, at 400.

31 See Members and Observers, available at http://www.wto.org/english/thewto_e/whatis_e/tif_e/org6_e.htm (last visited on Sept. 9, 2013). 
Accordingly, no politician can afford to ignore the attitudes of constituents. The Multilateral Agreement on Investment ("MAI") negotiations failed partly due to this political considerations, which focused more on costs. ${ }^{32}$

\section{Community Approach}

Inspired by the ideas of Simma on the implications of the emergence of the international community interest on bilateralism, ${ }^{33}$ Schill also contended that the multilateralization of international investment law is closely related to a community approach. Schill argued that multilateralism "stresses the primacy of international law over national interests, and presupposes that international relations are order on the basis of non-discriminatory principles that apply to all States."

First, why is the community approach taken in international affairs? Simma contended that the emergence of community interest and the recognition of its significance are the two fundamental reasons for shifting the traditional bilateralism approach to the community approach in international law. ${ }^{35}$ The foundation of the GATT is a prime example in this regard. In designing new legal regimes "to save succeeding generations from the scourge of war," ${ }^{36}$ the founding members of the UN recognized that "beggar my neighbor" trade policies prevailing in the 1930s was one of important causes for World War II. ${ }^{37}$ To date, the maintenance of peace is still considered as one of 'Ten Benefits' that WTO has helped bring about. ${ }^{38}$ In other words, World War II made the States recognize that free trade had become a significant 'community concern' or 'community interest,' therefore, a multilateral regime was necessary.

However, the story is quite different with respect to international investment. International investment played a minor role compared to international trade in the 1940s. Therefore, the regulation of international investment did not qualify as a 'community interest.' It was not until the 1990s that international investment became another 'engine' like trade for international economy. Nevertheless, it seems too early to argue that the regulation of international investment has

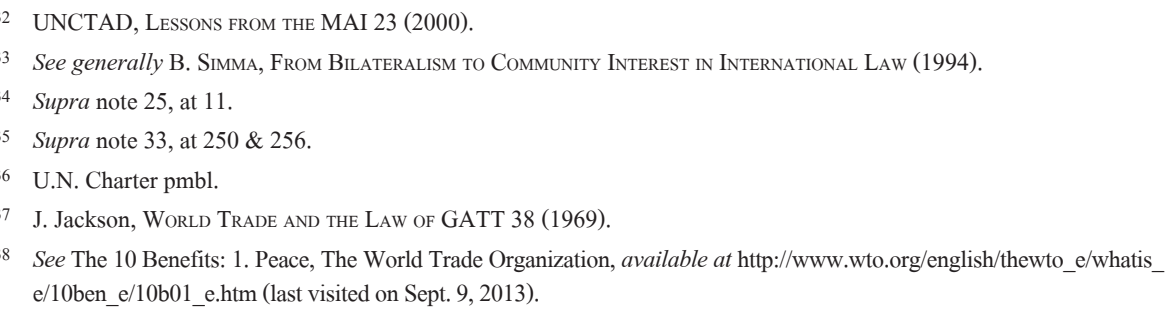


become a 'community concern' or 'community interest' in light of the current international investment structure. In 2005, the outward foreign direct investment from developing countries only accounted for about $17 \%$ of total outward Foreign Direct Investment ("FDI"). ${ }^{39}$ While developing countries significantly increased their share up to 29 percent in $2012,{ }^{40}$ most of this growth was contributed by a handful of developing countries, especially China. ${ }^{41}$ This implies that most States still have little interest in protecting their overseas investment in a multilateral manner.

According to Simma, multilateralism such as the GATT or the UN may be founded on the condition of 'community interest.' This means that multilateral regimes are 'fact-driven'; they are instrumentalized as a passive response to existing facts. However, such a passive manner might result in terrible losses, which have been demonstrated by the foundation of the GATT or the UN. One can argue that multilateral regimes can also be 'institution-driven.' In other words, a regime can be created or expanded for the 'community interest,' which, in turn, enlists more support from parties to the regime. As far as international investment is concerned, it is hard to argue that there is strong 'community interest' to support multilateral regime if monitoring the share of inflow FDI ("IFDI") to the 50 Least Developed Countries, nearly a quarter of all States across the world, is less than 2 percent out of total IFDI in $2011 .^{42}$ From the 'institution-driven' perspective, multilateral regimes on investment are still desirable.

Second, what is the proper meaning of the community approach? Indeed, multilateral governance, as a rule, requires some disciplines such as non-discrimination. However, the community approach should stop here. A noticeable characteristic of 'community' is 'solidarity,' which means the interests of the disadvantaged in a 'community' should be given special sympathy. ${ }^{43}$ Furthermore, as noted above, benefits and costs from a multilateral regime may be greatly disproportionate among different States. Therefore, one of the functions of the community approach is to seek to allocate benefits and costs among States within multilateral regimes as equitable as possible. Otherwise, these States may be reluctant either to support or maintain their support for multilateralism.

Again, the GATT/WTO provide a good example. In the 1960s, "Trade and Development" was added to the GATT in order to address the issue that trade

UNCTAD, 2006 World InVESTMENT Report 105 \& 107(2006).

UNCTAD, 2011 World InVESTMEnt Report 6 (2011).

41 Id. at 7.

42 UNCTAD, 2012 World InVESTMEnt Report 65 (2012).

43 See generally R. Wolfrum \& Chie Kojima eds, Solidarity: A Structural Principle of International Law (2010). 
conditions were worsening for developing countries. ${ }^{44}$ In 1979, "The Enabling Clause," which exclusively favors developing countries, provided exceptions to the MFN treatment. In other words, developing countries were granted with Special and Differential (“S\&D”) treatment. ${ }^{45}$ The Marrakesh Agreement Establishing the World Trade Organization (hereinafter WTO Agreement) continues such a policy. ${ }^{46}$ In particular, 'development' in favor of developing countries was set as a key agenda of the WTO Doha Round. ${ }^{47}$ Under this community approach, many preferential arrangements have been created for developing Members of WTO. ${ }^{48}$ It is presumed that developing Member support for WTO would be undermined without such arrangements. Similarly, the fact that Doha Round remains in stalemate after 10 years of prolonged negotiations can also be partly explained from the community perspective: S\&D arrangements enshrined in the WTO Agreement have not been implemented effectively in practice. ${ }^{49}$

This community approach has long been advocated by developing countries in the New International Economic Order ("NIEO") movement since the 1960s. ${ }^{50}$ To this end, developing countries appealed that "the agreed differences in development of the developing countries and their specific needs" should be taken into account. ${ }^{51}$ While some propositions of developing countries in the NIEO movement are open to debate, ${ }^{52}$ this community approach is acceptable and should be respected.

44 GATT pt. IV (1947).

45 See Decision on Differential and More Favourable Treatment, Reciprocity and Fuller Participation of Developing Countries (Nov. 28, 1979) L/4903.

46 Marrakesh Agreement pmbl.

47 WTO, Ministerial Declaration, WT/MIN(01)/DEC/1 (Nov. 14, 2001) ๆ 44, available at http://www.wto.org/english/ thewto_e/minist_e/min01_e/mindecl_e.htm (last visited on Sept.1, 2013).

48 See, e.g., Agreement on Trade-Related Investment Measures art. 5(2).

49 Supra note 47.

50 G.A. Res. 3281(XXIX), pmbl, U.N. Doc. A/RES/29/3281 (Dec. 12, 1974).

$51 \quad$ Id.

52 J. Tepe, The Charter of Economic Rights and Duties of States: A Reflection or Rejection of International Law?, 9 INT'L LAW. 295(1975). 


\section{What can TPP Negotiators Learn from Prior Attempts to Multilateralize International Investment Law?}

\section{A. Introduction}

From the perspective of the TPP negotiations regarding investment, one should focus on prior attempts within the GATT/WTO and OECD for two reasons. First, the negotiations on investment in both the TPP and GATT/WTO are integrated into broader bargains. This gives negotiating parties flexibility to bargain over many issues and reach a package deal. The second is that, while negotiations on investment in both the TPP and OECD are regional in nature, both have profound multilateral implications.

While the Havana Charter for an International Trade Organization (hereinafter Havana Charter) focuses on trade, it is also related to investment. The Havana Charter stressed the 'great value' of international investment for "economic development and reconstruction, and consequent social progress" and seemingly took it for granted that investment treaties would promote investment. ${ }^{53}$ Interestingly, the Havana Charter was devoted in a large extent to developing countries whose concern was to protect their sovereignty, rather than those of the US, a State playing a significant role in drafting the Havana Charter and who intended this instrument to provide a shield for its oversea investment. The Havana Charter stressed that a host State would have the 'right' to "take any appropriate safeguards necessary" to prevent foreign investment from being used as a basis for "interference in its internal affairs and national policy." Furthermore, a host State would have the right to determine "whether and, to what extent and upon what terms it will allow future foreign investment. ${ }^{54}$ As such, the US was dissatisfied with the Havana Charter. ${ }^{55}$

Although the intention of the US to create an investment regime within the multilateral trade regime was frustrated in the 1940s, it did not stop such endeavors. E.g. the US proposed that the investment agenda be included in the GATT Tokyo Round negotiations. It was not successful again due to strong resistance from developing countries. ${ }^{56}$ However, in the 1980s, they witnessed the US successfully include investment as a new negotiation agenda in the GATT. In 1982, the US

53 Havana Charter art. 12.1 (a) \& (b).

54 Id. art. 12.1 (c).

55 S. Quillin, The World Trade Organization and Its Protection of Foreign Direct Investment, 28 OKLA. CITY U. L. REv. $875 \& 882$ (2003).

56 J. Kurtz, A General Investment Agreement in the WTO?, 23 U. PA. J. InT'L Econ. L. 713 \& 722(2002). 
referred a dispute to the GATT regarding Canada's foreign investment review mechanism. ${ }^{57}$ The GATT Panel decided that the requirement by Canada asking foreign investors to satisfy the obligations in terms of local content and export performance breached the GATT's provision of national treatment, ${ }^{58}$ giving the US another opportunity to argue for the inclusion of investment issues within the GATT. Furthermore, the US and like-minded States offered promises, e.g., more market concessions on trade in goods, in exchange for developing countries' supports to negotiate investment rules within the GATT. As a result, investment became an important negotiation agenda item during the GATT Uruguay Round. Nevertheless, many liberal commitments proposed by developed countries were rejected or watered down, e.g., the scope of the Trade-Related Investment Measures ("TRIMs") covered by the TRIMs Agreement is far more limited than those envisaged by developed countries. ${ }^{59}$

Even though a comprehensive investment regime was not developed during the GATT period, developed countries kept on pursuing such efforts. At the 1996 Singapore Ministerial Meeting, developed countries proposed an initiative to enhance negotiations on investment rules, which was opposed by most developing countries led by India, Malaysia, Egypt and Uganda. Notwithstanding, at that occasion, it was decided to "establish a working group to examine the relationship between trade and investment." ${ }^{60}$ Five years later, developing countries' attitudes changed somewhat positively. They recognized the desirability of a multilateral investment regime and agreed to launch negotiations. ${ }^{61}$ On the other hand, these countries stressed once again that their special needs for development should be given favorable consideration. ${ }^{62}$ Therefore, it can be assumed that developing countries could accept an 'institution-driven' multilateral regime on investment. However, no actual progress has been achieved since then. In August 2004, the WTO General Council decided that investment issues would be excluded from the Work Program set out in the Doha Ministerial Declaration; no work in this respect would

57 GATT Panel Report, Canada - Administration of the Foreign Investment Review Act ("FIRA"), L/5504 (Feb. 7, 1984) BISD 30S/140, available at http://www.worldtradelaw.net/reports/gattpanels/gattpanels.asp (last visited on Sept. 10, 2013).

58 See FIRA Panel Report, at 160; GATT art. 3(4).

59 Supra note 56, at 888.

60 See Singapore Ministerial Declaration, WT/MIN(96)/DEC (1996), ๆ20, available at http://www.wto.org/english/ thewto_e/minist_e/min96_e/wtodec_e.htm (last visited on Sept. 10, 2013).

61 See Doha Ministerial Declaration, WT/MIN(01)/DEC/1 (2001), ๆ 20, available at http://www.wto.org/english/thewto_ e/minist_e/min01_e/mindecl_e.htm (last visited on Sept. 10,2013).

62 Id. $\llbracket 21$. 
be undertaken during the Doha Round. ${ }^{63}$

The MAI negotiations were initiated by and confined to the OECD Member States since the mid-1990s. This MAI program represented the most ambitious attempt to multilateralize international investment law after World War II, even though it is regional in nature. In 1991, two subordinate bodies of OECD, the Committee on International Investment and Multinational Enterprises ("CIME") and the Committee on Capital Movements and Invisible Transactions (“CMIT"), started to consider the possibility of negotiating a comprehensive international investment instrument. In 1995, they suggested that "the time is ripe to negotiate a MAI" because the significant growth of FDI flows over the past years benefited not only OECD countries, but also a growing number of non-OECD countries. ${ }^{64}$ Obviously, they presumed that multilateral governance of investment was not a regional concern any longer, but a global concern. OECD realized that WTO would not be a favorable forum for negotiation as most members were developing countries. Rather, OECD would better suit the interests of developed countries. ${ }^{65}$ OECD could thus infer that a multilateral goal could be achieved with regional means. In other words, a regional program could have profound multilateral implications. This intention was confirmed by the fact that, from the outset, MAI was designed not to be confined to the OECD Member States, ${ }^{66}$ but open to non-OECD States. ${ }^{67}$ OECD Member States did not worry much that the MAI negotiations were conducted in a closed manner in such a way that would prevent MAI from being accepted by developing countries. Indeed, some developing countries were believed to embrace MAI due to the pressure. ${ }^{68}$

The MAI negotiations were aimed to "set a high standard for the treatment and protection of investment" and "achieve a high standard of liberalization covering

63 See Doha Work Program, WT/L/57 (2004), available at http://www.un.org/special-rep/ohrlls/lldc/Doha\%20Work\%20 Programme.doc (last visited on Sept. 10, 2013).

64 See Report by CIME and CMIT, May 5, 1995, available at http://www1.oecd.org/daf/mai/htm/cmitcime95.htm (last visited on Sept.1, 2013).

65 In explaining why the non-OECD States were not invited to participate in MAI negotiations, the Chair of the Negotiating Group for MAI negotiations argued that "....mainly because experience shows that the more countries are involved, the slower the pace of work." See Huiping Chen, OECD's Multilateral Agreement on Investment: A Chinese Perspective 15 (2002). Since all developed States are members of OECD, it can be argued that developed States do not favor developing States, in particular several key developing States such as China, India and Brazil, to engage in negotiations.

66 They include Australia, Austria, Belgium, Canada, Czech Republic, Denmark, Finland, France, Germany, Greece, Hungary, Iceland, Ireland, Italy, Japan, Korea, Luxembourg, Mexico, Netherlands, New Zealand, Norway, Poland, Portugal, Spain, Sweden, Switzerland, Turkey, United Kingdom, and United States. Currently, OECD has 34 Members.

67 Supra note 64.

68 Supra note 65, at 15. 
both the establishment and post-establishment phase. ${ }^{\circ 9}$ The negotiations were expected to be completed by the 1997 OECD Ministerial Meeting. Because of unexpected and serious disagreements from within and outside the negotiating parties, ${ }^{70}$ however, the deadline was postponed to the 1998 Ministerial Meeting. In October 1998, France, a once major advocate of MAI negotiations, declared that she withdrew from the MAI negotiations and several other influential States such as Australia, Canada, Germany and UK also dropped their support of the MAI negotiations. In December 1998, OECD could not but declare that the MAI negotiations had ceased. ${ }^{71}$

\section{B. Main Lessons from the Past Attempts}

\section{How to Evaluate the Role of Great Powers}

Oppenheim once argued that great powers were "the leaders of the Family of Nations" and the progress of international law was "the result of their political

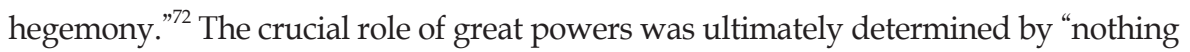
else than [their] actual size and strength," even though Oppenheim recognized that it was "a minor Power" that frequently took "initiative towards the progress." ${ }^{" 73}$ Human history has also shown that multilateral institutions, in practice, are often dominated by a handful of great powers. ${ }^{74}$

Investment rule-making within the GATT/WTO and OECD shows that Oppenheim's proposition still applies considering that investment issues obviously would not have been included into the Havana Charter due to strong opposition of the US, the sole country capable of conducting large outward investments in the 1940s. Similarly, the US was crucial in expanding coverage of GATT to include investment in the 1980s. Conversely, the reluctance of the US to lead the MAI negotiations was an important factor for the failure of MAI, even though the negotiations within OECD did originate from an initiative it proposed in

69 Id.

70 Id. at $13-16$.

71 P. Muchlinski, The Rise and Fall of the Multilateral Agreement on Investment: Where Now?, 34 InT'L LAW. 1033 (2000). See also C. Baumgartner, The Demise of the Multilateral Agreement on Investment, 10 CoLO. J. INT'L ENvTL. L. \& PoL'y 40(1999).

72 L. Oppenheim, International Law 170 (2d ed. 1912).

73 Id. at 171. The establishment of International Criminal Court provides a more recent example showing that minor States can do better than GPs in advocating initiative of progress. See D. Chatoor, The Role of Small States in International Diplomacy: CARICOM's Experience in the Negotiations on the Rome Statute of the International Criminal Court, 7 INT'L PEACEKEEPING 295 (2001).

74 Supra note 8 , at $12 \& 34$. 
$1991 .^{75}$ Similarly, France arguably withdrew mainly due to the demise of the MAI negotiations. $^{76}$

Nonetheless, the role of developing countries should not be ignored because they have been increasingly influential in international affairs since World War II. This is not only because the principle of sovereign equality ${ }^{77}$ enables them to bargain with developed countries on an equal legal footing, but also because their political power as a whole has expanded significantly. Among the 23 States who signed the Final Act for the establishment of the GATT, e.g., only ten parties were from the West. ${ }^{7879}$ The protection of sovereignty was a prior concern for non-Western States because their political independence was often encroached by Western powers in recent history. ${ }^{80}$ This awkward negotiating structure was a major reason a multilateral investment treaty was not adopted, in spite of the fact that the investment issue was included in the Havana Charter negotiations.

Therefore, great powers were tactically wise enough to shift the investment negotiations from WTO to OECD in the 1990s. As such, the powers that be could fully take advantage of their predominant power and resources. Meanwhile, some commentators maintained that the civil protest from developing countries was an important factor for the failure of the MAI negotiations. ${ }^{81}$ However, developing countries were not entitled to block negotiations to which they were not negotiating parties. Furthermore, neither did such nations have institutional support as they did in the GATT/WTO where they can mobilize quite effectively to engage with developed countries.

\section{How to Evaluate the Limit of 'High Standards'?}

Negotiations on investment rules within OECD and the GATT/WTO raised other concerns, namely, that developed and developing countries alike would oppose 'high standards.'

With regard to the MAI negotiations, OECD officials appeared confident to believe that "the MAI exercise was primarily a task of assembling the technical

75 Muchlinski, supra note 71, at 1039.

76 Baumgartner, supra note 71 , at 47.

77 U.N. Charter art. 2.

78 They are Australia, Belgium, Canada, France, Luxemburg, Netherlands, New Zealand, Norway, the U.K. and the US.

79 Non-Western States refer to Brazil, Burma (now Myanmar), Ceylon (Now Sri Lanka), Chile, China, Cuba, Czechoslovak, India, Lebanon, Pakistan, Southern Rhodesia (now Zimbabwe), Syria, and South Africa.

80 See generally G. Gong, The Standard of ‘Civilization' in International Society (1984).

81 L. Kelly, Multilateral Investment Treaties: A Balanced Approach to Multilateral Corporations, 39 Colum. J. TRAnSNAT'L L. 483 \& 495-496 (2001). See also supra note 66, at 15. 
elements from various existing international investment agreements into a rational whole." ${ }^{82}$ Therefore, they suggested very limited exceptions and temporary deviations from general disciplines. As negotiations progressed, however, they began realizing that negotiations might fail without increased flexibility. Thus, a "country-specific approach" was adopted and the OECD Member States listed some exceptions which they deemed necessary in light of their specific national circumstances. ${ }^{83}$ The MAI draft became littered with exceptions, ${ }^{84}$ and a 'technical' exercise evolved into a 'political' one. ${ }^{85}$

In the GATS, developed countries are far more competitive than developing countries with respect to trade in services, and the pursuit of 'high standards' in this area is of great importance. However, developed countries accepted a more moderate approach than in the MAI negotiations, consisting of the following three primary features. First, liberalization will be realized progressively rather than once and for all. The GATS provides 'successive' rounds of negotiations after entering into force. ${ }^{86}$ It also employs a 'positive approach' rather than 'negative one.' Eventually, WTO Members are not obliged to liberalize those sectors and matters which are not listed in Schedules of Specific Commitments. ${ }^{87}$ Second, liberalization has different meaning among different WTO Members and to different matters. The GATS stipulates that the liberalization "shall take place with due respect for national policy objectives and the level of development of individual Members." ${ }^{88}$ Third, commitments can not only be moved on but be drawn back. Any WTO Member is authorized to 'modify' or 'withdraw' their commitments under certain conditions. ${ }^{89}$ But for such a moderate approach, consensus would not have been reached among States, especially between developed and developing States.

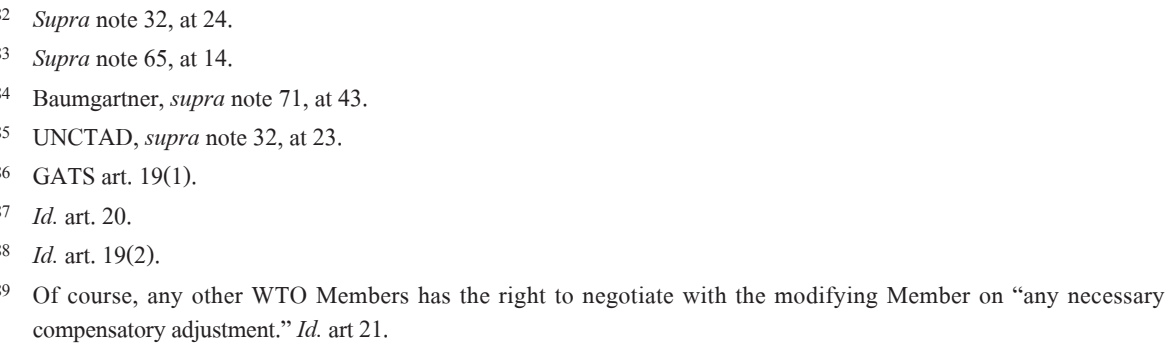




\section{Potential Implications of TPP Negotiations on the Multilateralization of International Investment Law}

\section{A. A Brief Description of the Investment Agenda in TPP Negotiations}

Before the negotiation drafts were leaked in June 2012, little was known as to either the text or the process of negotiations regarding investment rules. Numerous comments were nevertheless made by various actors including individuals and NGOs. Generally, they did not oppose negotiations on investment rules, but rather put forward a range of suggestions, such as allowing national measures to prevent and mitigate financial crises, creating a level playing field between State-owned and private enterprises, and preventing investors from abusing investment treaties. ${ }^{90}$ Among various issues, the dispute settlement mechanism ("DSM") provoked debates because the investor-State DSM has been undergoing serious doubts and criticism for over a decade. ${ }^{91}$ Some comments suggested that the investor-State DSM prevalent in current investment treaties should be replaced by the State-State DSM. ${ }^{92}$ Others suggested that the principle of local remedies be respected. ${ }^{93}$

The only official description on the progress of TPP negotiations on investment rules was outlined by the negotiating parties in November 2011 (hereinafter the 2011 Outline):

The investment text will provide substantive legal protections for investors and investments of each TPP country in the other TPP countries, including ongoing negotiations on provisions to ensure non-discrimination, a minimum standard of treatment, rules on expropriation, and prohibitions on specified performance requirements that distort trade and investment. The investment text will include provisions for expeditious, fair, and transparent investor-State dispute settlement subject to appropriate safeguards, with discussions continuing on scope and coverage. The investment text will protect the rights of the TPP countries to regulate in the public interest. ${ }^{94}$

See, e.g., Earthjustice et al., Investment Rules in Trade Agreements: Top 10 Changes to Build a Pro-Labor, ProCommunity and Pro-Environment Trans-Pacific Partnership, at 1-2, Aug. 9, 2010, available at http://www.citizen.org/ documents/InvestmentPacketFINAL.pdf (last visited on Sept. 9, 2013).

91 Supra note 21.

92 See, e.g., A letter to trade ministers of Australia, Brunei Darussalam, Chile, New Zealand, Peru, Singapore and the US, Feb. 4, 2011, available at http://tppdigest.org/images/stories/finaltppinvestmentletter.doc (last visited on Sept. 9, 2013).

93 Supra note 93

94 USTR, Outlines of the Trans-Pacific Partnership Agreement: Enhancing Trade and Investment, Supporting Jobs, 
Two important points in the 2011 Outline are worth mentioning. First, it appears that the TPP negotiating parties intend to negotiate a more balanced regime rather than a liberal such as MAI. Interestingly, terms such as 'liberalization,' 'high standards', which were often found in the MAI negotiations, do not appear at all in TPP. Rather, it stresses the host States' authority to protect public interest. Second, some disagreements exist, e.g., regarding the scope and coverage of the proposed Investment Chapter.

Following the leak of the Investment Chapter, it became apparent that the text was tantamount to the 2012 US Model BIT, ${ }^{95}$ which, with some moderate revisions, was developed from the 2004 US Model BIT, ${ }^{96}$ and, earlier, from the Chapter 11 of the North American Free Trade Agreement ("NAFTA"). In a word, it can be assumed that the US has taken a leading role in the negotiations.

\section{B. Implications of the TPP Investment Chapter Negotiations}

Although negotiations over the TPP Investment Chapter are regional and ongoing, they will have global implications. The 2012 World Investment Report, e.g., has paid special attention to TPP developments. ${ }^{97}$ One implication is that as more States join, TPP may evolve into to a multilateral or quasi-multilateral treaty, as the MAI negotiations intended to do; likewise, the TPP Investment Chapter might become a basis or a model for new multilateral rule-making on investment.

Currently, the TPP parties include a group of 11 diverse States. The P4 Agreement is the first multi-party free trade agreement linking Asia, the Pacific, and Latin America. ${ }^{98}$ These eleven participating States include developing and developed countries, both powerful and small Countries, Capitalist States and Socialist States, and States with various religious and cultural backgrounds. ${ }^{99}$

Members of the Asia-Pacific Economic Cooperation (“APEC”), ${ }^{100}$ who are not

Economic Growth and Development, Executive Office of the President of the United States (Nov. 12, 2011), available at http://www.ustr.gov/about-us/press-office/fact-sheets/201 1/november/outlines-trans-pacific-partnership-agreement (last visited on Sept. 10, 2013).

952012 U.S. Model Bilateral Investment Treaty, available at http://www.ustr.gov/sites/default/files/BIT\%20text\%20 for\%20ACIEP\%20Meeting.pdf (last visited on Sept. 9, 2013)

962004 U.S. Model Bilateral Investment Treaty, available at http://www.state.gov/documents/organization/117601.pdf (last visited on Sept. 9, 2013).

97 Supra note 42 , at $84-85$.

98 Lewis, supra note 3, at 404.

99 See also pt. IV.C \& E.1.

100 As of September 2012, APEC has 21 Members. They include Australia, Brunei, Canada, Chile, China, Hong Kong, Indonesia, Japan, Korea, Mexico, Malaysia, New Zealand, Papua New Guinea, Peru, Philippines, Russia, Singapore, Chinese Taipei, Thailand, United States, and Vietnam. 
currently involved in TPP negotiations, may find untenable to simply act as bystanders during the negotiations. First, the P4 Agreement stresses that the Agreement is open to accession by "any APEC Economy." ${ }^{101}$ Second, TPP negotiations arguably serve "the most credible pathway to broader Asia-Pacific economic integration" 102 and an instrument to reach to a Free Trade Area of the Asia Pacific, ${ }^{103}$ a primary goal of regional integration by the APEC Members at their 2010 Summit. ${ }^{104}$ Third, those currently not involved in TPP negotiations may be concerned with the potential effect of the 'investment shift' arising from the would-be TPP Agreement. ${ }^{105}$ In fact, several other APEC Members are prepared to engage in TPP negotiations. For example, Japan decided to join TPP negotiations in March $2013^{106}$ and Korea and Taiwan have expressed their interest, as well. ${ }^{107}$ Considering that APEC Members account for 40 percent of the world population, 44 percent of global trade and 53 percent of world GDP, ${ }^{108}$ and, in particular, investment liberalization is an established agenda of the APEC, ${ }^{109}$ the potential economic and legal significance of a TPP investment regime is of great significance. Furthermore, TPP negotiations are not confined to APEC Members. ${ }^{110}$ Several non-APEC States such as Costa Rica and Colombia have also expressed interest in joining TPP negotiations. ${ }^{111}$

From an economic perspective, among the existing 11 negotiating parties, there include four major economies such as Australia, Canada, Mexico and the US. As far

\footnotetext{
101 P4 Agreement art. 20.6.

102 See The United States in the Trans-Pacific partnership, Executive Office of the President of the United States, available at http://www.ustr.gov/about-us/press-office/fact-sheets/2011/november/united-states-trans-pacific-partnership (last visited on Sept 30, 2013); P4 Agreement Pmbl.

103 M. Lewis, The Trans-Pacific Partnership: New Paradigm or Wolf in Sheep's Clothing?, 34 B. C. InT'L \& Comp. L. Rev. 28 (2011).

104 See Leaders' Declarations: Pathways to FTAAP, APEC (Nov. 14, 2010), available at http://www.apec.org/MeetingPapers/Leaders-Declarations/2010/2010_aelm/pathways-to-ftaap.aspx (last visited on Sept. 9, 2013).

105 Even though no definite evidence has been found to support that, as a rule, the conclusion of investment treaties will significantly affect the direction of capital flow.

106 See Press Conference by Prime Minister Shinzo Abe, Prime Minister of Japan and His Cabinet (Mar. 15, 2013), available at http://www.kantei.go.jp/foreign/96_abe/statement/201303/15kaiken_e.html (last visited on Sept. 9, 2013).

107 See I. Fergusson et al., The Trans-Pacific Partnership Negotiations and Issues for Congress, CRS Report for Congress (Aug. 21, 2013), at 5, available at http://www.fas.org/sgp/crs/row/R42694.pdf (last visited Sept.1, 2013).

108 See Achievements and Benefits, APEC, available at http://www.apec.org/About-Us/About-APEC/Achievementsand-Benefits.aspx (last visited on Sept 9, 2013).

109 See, e.g., APEC Non-Binding Investment Principles (1994), available at http://unctad.org/Sections/dite/iia/docs/ compendium/en/52\%20volume\%202.pdf; Options for Investment Liberalization and Business Facilitation to Strengthen APEC Economies (1997), available at http://www.apec.org/Groups/Committee-on-Trade-and-Investment/ /media/ Files/Groups/IEG/03_cti_ieg_optionbizlib.pdf (last visited on Sept. 2, 2013).

110 P4 Agreement art. 20.6.

111 Supra note 107, at 5.
} 
as investment flow, in 2010, the US, Singapore, Australia, Canada and Mexico were ranked the top 20 host States, and the US, Singapore, Australia, Canada were among the largest 20 investment destinations. ${ }^{112}$

From a legal perspective, the involvement of the US, the most innovative actor in international investment law and the de facto leading State in TPP negotiations, might bring some new input into the current investment regime. TPP negotiations would directly affect the future application of investment treaties among the current negotiating parties. Depending on its implementation, more investment treaties between TPP negotiating parties and non-TPP negotiating parties may be indirectly affected by the TPP investment regime. ${ }^{113}$

\section{Strategies for TPP Investment Chapter Negotiations}

The multilateralization of investment governance has yet to be successful. Due to repeated failures, one may be worried if TPP negotiations were to result in a similar fashion to the MAI negotiations. However, TPP negotiations are expected to be more fruitful than in the past.

First, several developing countries are taking the initiative to negotiate an investment regime in the framework of TPP. There are few hegemonic developed States except for the US in the core group. Serious disagreements between developing and developed countries over issues, such as the standard of compensation for expropriation and investment admission, have always been a critical factor repeatedly preventing multilateral investment rule-making. As commonly shown in the past negotiations in Havana, MAI, and Doha, the initiatives of developed States were frequently discouraged by developing States. Developed States were often criticized for focusing on the interests of investors, most of whom are their nationals.

Throughout history, great powers have been accused of abusing their power against small countries. ${ }^{114}$ Because all four Contracting States of the P4 Agreement are developing countries (Brunei and Chile) or developed but non-hegemonic countries (New Zealand and Singapore), initiatives may be freely proposed in the course of negotiations without coercion from great powers. In accordance with the

\footnotetext{
112 UNCTAD, supra note 42, at 8-9.

113 See Bilateral Investment Treaties, UNCTAD, available at http://www.unctadxi.org/templates/DocSearch_779.aspx; Treaty Agreements Database, UNSCAP, available at http://www.unescap.org/tid/aptiad/agg_db.aspx (last visited on Sept. 10, 2013).

114 See generally A. Anghie, Imperialism, Sovereignty and the Making of International Law (2004).
} 
objectives enshrined in the P4 Agreement ${ }^{115}$ and their high standards regarding trade matters, ${ }^{116}$ they would arguably have interest in a 'high standards' vis-àvis an investment regime. As such, no parties should be disregarded in the TPP negotiations, although the text for its investment chapter was mainly provided for by the US. The TPP Investment Chapter would be thus a common cause of most of the negotiating parties, not something to be worked out behind closed doors. As a result, confrontations between developed and developing countries prevalent in prior negotiations may not be an issue in the context of TPP. Nevertheless, it is not clear what 'high standards' mean in the eyes of the original P4 because the P4 Agreement itself does not include an Investment Chapter. As shown from the MAI failures, it is unclear whether 'high standards' will be readily accepted by the TPP negotiating parties.

When the P4 States started negotiations on investment rules in 2008, the US played a leading role. In particular, President Obama in his second term would speed up the TPP negotiations in order to qualify him as "America's first Pacific President" and to position the US as "a Pacific nation" to "strengthen and sustain our (US) leadership in this vitally important part of the world." 117

Second, there was not a robust network between major non-European OECD Member States and major European OECD Members during the MAI negotiations. This was an important reason why there was no consensus to the meaning of 'high standards' in investment regimes, even though almost every OECD Member State advocated for such 'high standards.' Serious disagreements unexpectedly arose.

In contrast, a network of investment treaties has been set up among TPP negotiating parties. As the negotiation text was provided by the US, it is appropriate to review this network from the American perspective. To date, the US has concluded investment treaties with six out of the 10 TPP negotiating States: four bilateral FTAs including Investment Chapters with Australia (2003), Peru (2006), Chile (2003), and Singapore (2003), and NAFTA, with Mexico and Canada (1993). All of these Investment Chapters are based on the NAFTA or 2004 US Model BIT. As for Brunei Darussalam and New Zealand, while they have not signed BITs or FTAs including Investment Chapters with the US, they are founding States of the P4 Agreement. Obviously, these existing treaty frameworks have substantially reduced discrepancies in TPP negotiations. It is thus sensible not to invite other great powers,

115 P4 Agreement art 1.1.

116 Id. ch. 3.

117 See Remarks by President Barack Obama at Suntory Hall, The White House (Nov. 14, 2009), available at http://www. whitehouse.gov/the-press-office/remarks-president-barack-obama-suntory-hall (last visited on Sept. 9, 2013). 
especially China to negotiations since some important divergences remain between China and existing TPP negotiating parties, especially the US, ${ }^{118}$ even though the inclusion of China is of significance for the future of TPP and is believed to be an important policy goal for the US. ${ }^{119}$

Nevertheless, disagreements exist and may arise during negotiations among TPP negotiating parties. In addition to the disagreements indicated in the 2011 Outline, Australia significantly shifted its attitude towards the investor-State DSM. This kind of DSM is a core element of foreign investment treaties and has always been pursued by developed countries including Australia. In April 2011, however, the Gillard Government issued a trade policy statement, ${ }^{120}$ which declared that Australia would discontinue the traditional practice of seeking "the inclusion of investor-state dispute resolution procedures in trade agreements with developing countries at the behest of Australian businesses." ${ }^{121}$ It suggested that Australian investors with a plan to invest in the developing world "need to make their own assessments about whether they want to commit to investing in those countries." ${ }^{122}$ In early 2003, Australia, in its FTA with the US, rejected the investor-State DSM arguing that, as a developed host State, Australia could protect foreign investors well.

There are complicated grounds for criticizing investor-State DSM. Critics believe that investment tribunals would often interpret investment treaties too broadly. More importantly, substantive contents of those treaties are ambiguous so that it may be difficult for different tribunals to apply them in a consistent way. In this case, it is not legitimate to attribute substantive deficiencies to procedural failures. A better choice for TPP negotiating parties is, in addition to improving substantive provisions, ${ }^{123}$ to refine the investor-State DSM, ${ }^{124}$ rather than throw it away. ${ }^{125}$

Third, the more States involved in discussions generally correlates to less efficient negotiations. Trade negotiations within the GATT/WTO provide convincing evidence. In the past sixty years, negotiation periods for each 'Round' are generally

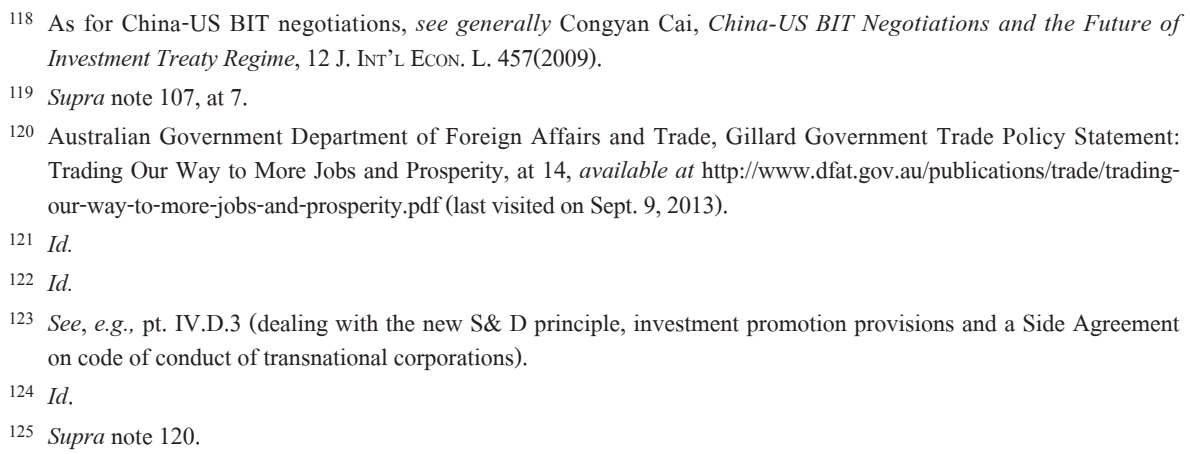


extended and prolonged. While some other factors such as the expansion of issues are partly to blame, the dramatic increase in the number of parties is a critical. factor. As far as the MAI negotiations, there were twenty-nine OECD Member States involved in negotiations in 1998. Currently, there are only 11 States participating in TPP negotiations. Consequently, negotiations may be conducted more efficiently in the TPP context than those in the MAI and WTO contexts.

\section{Towards a Model Multilateral Investment Regime}

\section{A Brief Critique on the Modern Investment Treaty Regime}

The modern investment treaty regime was born in the mid-twentieth century in order to protect and promote international investment. Since then, the investment treaty regime has been undergoing unprecedented criticism, which come from both developing countries ${ }^{126}$ and even developed countries. ${ }^{127}$ This regime has also been reproached by the civil society across the world. ${ }^{128}$

In this regard, several proposals are suggested to refine the current investment treaty regime through restructuring the relationship between developing and developed countries, between host States and foreign investors, and economic and non-economic concerns. ${ }^{129}$ Since TPP Investment Chapter negotiations may bring about profound multilateral implications, it is anticipated that they can contribute much to the process of multilateralization of international investment law.

\section{What TPP Negotiating Parties Have Done?}

Although no further official message on investment regime has been released since the leaked text, recent practices of several TPP negotiating parties would suggest what they have done to improve their investment treaties, which may be developed further in the TPP negotiations.

The US should be mentioned first because it has not only provided the negotiation text of TPP Investment Chapter, but also played a leading role in the recent global reconstruction of the investment treaty regime. As a response to having been sued

126 Wenhua Shan, Is Calvo Dead?, 55 Am. J. Comp. L. 142 (2007).

127 Bipartisan Trade Promotion Authority Act (“BTPA”), 19 U.S.C. $\$ 3802$ (2002).

128 H. Mann et al., IISD Model International Agreement on Investment for Sustainable Development, International Institute for Sustainable Development, available at $\mathrm{http} / / \mathrm{www}$. iisd.org/pdf/2005/investment_model_int_agreement. pdf (last visited on Sept. 9, 2013).

129 Congyan Cai, Regulation of Non-Traditional Investment Risks and Modern Investment Treaty Regime in the Era of Late Globalization, 7 MANCHESTER J. INT'L Econ. L. 27-34 (2010). 
several times under the NAFTA Chapter 11, the US enacted the 2002 BTPA, ${ }^{130}$ which to reform its model for investment treaties. Indeed, the US maintains its traditional attitude in favor of investment liberalization because the 2002 BTPA stresses that the principal negotiating objectives of the US regarding investment "are to reduce or eliminate artificial or trade-distorting barriers to foreign investment... to secure for investors important rights comparable to those that would be available under United States legal principles and practice." ${ }^{131}$ However, the BTPA does not give foreign investors more favorable substantive treatment than national investors. ${ }^{132}$ In particular, it provides how to make international settlement mechanisms more transparent and controllable in order to protect its public authority. ${ }^{133}$ Such elements were incorporated in the 2004 US Model BIT. Together with Canada and Mexico, the US prompted the NAFTA Free Trade Commission ("FTC") to issue several Notes which clarified some ambiguous provisions or terms including the concepts of the minimum standard of investment treatment. ${ }^{134}$

Comparing the new American practices to investment treaties to those before the 2004 Model BIT, Alvarez rightly appraised that: "The object and purpose of the 2004 Model is less about the investor and more about the rule of law itself." He added: "The purposes of the new BITs and FTAs appear to include, much more explicitly, the goal of 'balancing' the rights of private investors on the one hand and States on the other. Post-2004 US treaties emphasize far more than its old BITs the need for States to regulate in the public interest." 135

Australia is another State which plays a key role in negotiating a good TPP Investment Chapter. In addition to its new - arguably hostile - attitude towards the investor-State DSM, the Gillard Government decided that it would not support provisions "that would confer greater legal rights on foreign businesses than those available to domestic businesses." ${ }^{136}$ Furthermore, Australia would not support provisions that would damage its ability to make laws on social, environmental and economic matters which would not be used to discriminate between domestic and foreign businesses. ${ }^{137}$

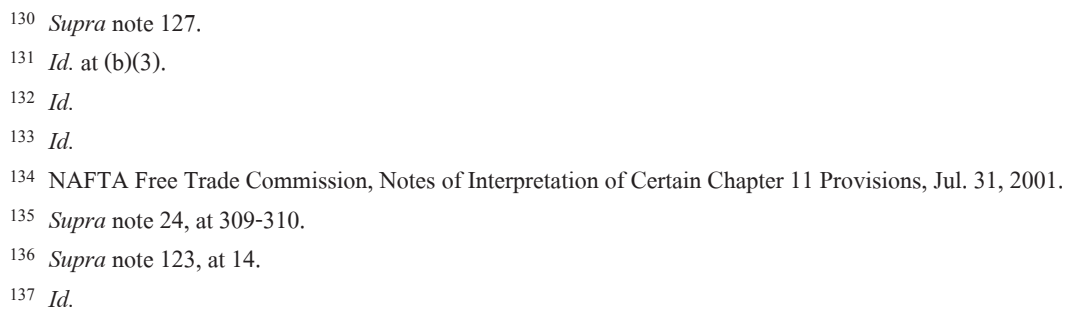




\section{What More Could TPP Negotiating Parties Do?}

While some TPP negotiating parties, in particular the US, have taken some measures to reform the current investment treaty regime, there are more that can be done.

First, a new principle of S\&D treatment should be included in the TPP Investment Chapter. The contemporary world is of great diversity. States are different in terms of geography, territory, population, economic development, cultural tradition, and national governance. As TPP negotiating parties are not an exception in this regard, a proper community approach is needed in order to organize these divergent States. As discussed above, the so-called generalized principles of conduct have not been adhered to rigidly and should be flexibly applied in the multilateral context, which can be discerned from the GATT/WTO granting the S\&D treatment to developing countries. The gap between developing and developed countries in terms of international investment is larger than that in terms of international trade. This disparity, however, has hardly been considered in drafting and implementing current investment treaties. These treaties should be, in principle, devoted to 'mutual' encouragement and protection of investment between Contracting States. As Sornarajah rightly pointed out, however, "the statement disguises the important fact that the flow that is really contemplated is in reality a one-way flow of investment form the developed state to the developing states." ${ }^{138}$

Probably inspired by the failure of MAI negotiations, the UNCTAD soon suggested that the S\&D treatment be included in investment treaties. ${ }^{139}$ Unfortunately, that suggestion appears not be taken seriously. It must be a significant development if the S\& D treatment could be incorporated in future TPP Investment Chapters.

Noticeable is that the prevailing S\&D arrangements in treaties are created out of economic concern. This concern remains in TPP negotiations because many developing countries would be potential parties. The diverse cultural and political backgrounds among Trans-Pacific States may be also the most conspicuous in the world. Socialist States such as China and Vietnam exist side by side with Capitalist States such as the US and Canada. States with Confucian traditions coexist with Christian and Islamic countries. Non-economic issues may be as difficult as, if not more, economic issues. ${ }^{140}$ The TPP Investment Chapter should thus include not only economic S\&D arrangements, but also non-economic S\&D arrangements.

138 M. Sornarajah, The International Law on Foreign InVestment 218 (2010).

139 UNCTAD, International Investment Agreements: Flexibility for Development, UNCTAD/ITE/IIT/18 (2000), at 29-36.

140 A major reason for France to withdraw their support from MAI negotiations is that it was deeply concerned that MAI negotiations would damage its cultural identity. Baumgartner, supra note 71, at 47. 
Second, some operative provisions on investment promotion should be included in the TPP Investment Chapter. Investment promotion is another important purpose for Contracting Parties to investment treaties, especially for developing countries. Investment treaties are, however, far less effective for investment 'promotion' than investment 'protection.' There has been no definitive evidence that investment treaties significantly promote investment flow. ${ }^{141}$ Theoretically, as discussed above, diffuse reciprocity as a benefit arising from multilateralism is often illusory. Therefore, effective provisions on investment promotion should be sought to make diffuse reciprocity a reality. Unfortunately, the leaked TPP Investment Chapter is silent in this regard.

To include effective investment promotion provisions may be an appropriate response to concerns that investment treaties "do not do enough to attract foreign investment." ${ }^{142}$ In current investment treaties, such provisions have their place in preambles. They are "normally of a very general nature, confirming the good intentions of the contracting parties to promote foreign investment through the conclusion of the investment treaties." ${ }^{143}$ Nevertheless, some investment treaties include investment promotion provisions in their operative part. Article 26 of the FTA between European Free Trade Association and Lebanon (2004), e.g., provides that investment promotion activities between the parties should take the form of "development of mechanisms for joint investments, in particular with small and medium enterprises of the Parties." ${ }^{144}$

Because overwhelming foreign investment is conducted by private investors, it is difficult, if not impossible, for host States to impose enforceable obligations on private investors requiring them to invest in a specific destination. Neither is it practical for them, on their own, to legally oblige themselves to invest in developing countries, even though some host States can promote capital flow through various instruments such as State owned enterprises. ${ }^{145}$ Even in this situation, however, many facilities, supports and incentives, even though which are obligatory for neither investors nor States, can work well in promoting investment flow to developing States. As the UNCTAD rightly suggested, if a voluntary commitment is

\footnotetext{
141 See generally K. Sauvant \& L. Schs, The Effect of Treaties on Foreign Direct Investment: Bilateral Investment Treaties, Double Taxation Treaties and Investment Flows 109-436(2009).

142 UNCTAD, Investment Promotion Provisions in International Investment Agreements, UNCTAD/ITE/IIT/2007/7 (2008), at 61 .

143 Id.

144 EFTA-Lebanon FTA art. 26(d).

145 'State enterprise' is also covered in investment treaties. See 2012 US BIT Model art. 1.
} 
properly implemented, "its effect might be as strong as a legally binding obligation." ${ }^{146}$

Third, a Side Agreement on code of conduct of transnational corporations in TPP Investment Chapter should be considered. As discussed above, whether benefits and costs from multilateral regimes are balanced among States may be crucial to maintain their continuous support. In the past, the focus was largely on the interactions between States which urged developed countries to make and honor commitments favorable to developing countries and to be accused of failing to do so. States negotiate and sign investment treaties, but investors take benefits directly from them. Investment claims which make host States suffer are not brought by home States or Contracting Parties to investment treaties, but by the investors, the beneficiaries of investment treaties. Therefore, in addition to the traditional Stateoriented perspective, the position of investors should also be considered in order to enhance a better investment regime.

Most investment treaties are silent on the conducts of investors. ${ }^{147}$ Rather, they focus on what and how States should or should not do. It is therefore not easy for investors to have clear guidelines for their business operations, and often are not interested in surveying investment treaties. ${ }^{148}$ They are even discouraged to act in such a manner that reduces the risks of disputes in investment with host States as much as possible.

The issue of conduct of investors has been considered by investment tribunals first. Muchlinski introduced in detail that the conduct of investors was considered by tribunals as an important factor in deciding whether host States have breached the obligation of fair and equitable treatment by investment treaties. ${ }^{149}$ However, some recent investment treaties have begun to regulate the conduct of investors in a direct manner. The 2004 US Model BIT, e.g., provides that foreign investors should deliver the host State a written notice of their intention to submit a claim of arbitration at least 90 days before their submission. ${ }^{150}$ These provisions are less systematic, however.

Legislatively, it is not appropriate to make a large number of provisions on the conduct of investors in the main body of investment treaties that, after all, are intended to regulate the rights and duties of States. A Side Agreement would be

146 UNCTAD, supra note 142, at 77.

147 S. Asante, The Concept of the Good Corporate Citizen in International Business, 4 ICSID REv. (1989).

148 Some surveys have found investor seldom have idea of investment treaties. See, e.g., J. Yackee, How much do US corporations know (and care) about bilateral investment treaties?, 31 COLum. FDI PeRsPeCtIVES (2010).

149 P. Muchlinski, “Caveat Investor?”: The Relevance of the Conduct of the Investor under the Fair and Equitable Treatment Standard, 55 InT'L \& CoMP. L. Q. 527 (2006).

1502004 US Model BIT art. 24(2). 
a good option and has been actually employed in the P4 Agreement. In addition to the main agreement, the P4 Agreement includes two side agreements such as Environment Cooperation Agreement and Labor Cooperation Memorandum of Understanding. These two side agreements are binding, however some of their provisions are "best endeavor clauses," ${ }^{151}$ and as such are non-binding.

Two suggestions are recommended for a Side Agreement regarding the conduct of investors. First, in addition to the OECD Guidelines and UN Draft, such an agreement should pay special attention to the behaviors of investors repeatedly described by arbitral tribunals. Second, the Side Agreement should be flexible and include not only obligatory provisions, but also non-obligatory provisions.

The last initiative is to establish an appellate mechanism for reviewing arbitral awards. Wälde observed that modern international investment law develops "mainly out of cases, and less out of treaties." 152 This observation has two implications. On the one hand, significantly growing investment treaties- based claims since the mid-1990s have made both States and investors realize the powerful 'muscle' of investment treaties. ${ }^{153}$ On the other hand, investment tribunals have garnered attention partly because they produced a number of awards which provoked controversies mainly due to conflicting interpretations of the same provisions in similar cases. ${ }^{154}$

As indicated above, the better response to criticism toward the investor-State DSM is to improve it. In this regard, the US obviously has taken a leadership role. "Providing for an appellate body or similar mechanism" is one of the negotiating objectives in the 2002 BTPA, whose purpose is to enhance the interpretation of investment treaties coherent. ${ }^{155}$ This objective was confirmed in the 2004 US Model BIT, which proposes two mechanisms for review of arbitral decisions: 'separate' (in the case of BITs) and 'multilateral' (in the case of multilateral treaty on investment) review mechanisms. ${ }^{156}$ Since 2003 , at least nine investment treaties signed by the US have mentioned the possibility of establishing a bilateral appellate mechanism. ${ }^{157}$ In

151 Environment Cooperation Agreement among the Parties to the Trans-Pacific Strategic Economic Partnership Agreement art. 2(1) \& (2).

152 T. Walde, New Aspects of International InVestment Law 66 (2006).

153 It is said that no more than two cases were registered before the ICSID before the mid-1990s. See I. Shihata, The Settlement of Disputes Regarding Foreign Investment, 1 Am. J. INT'L L. 104-106(1986).

154 Supra note 24, at 394-404.

155 Supra note 127 , at (b)(3).

1562004 US Model BIT art. 28(10).

157 See Dominican Republic-Central America-US FTA annex 10-F; US-Chile FTA annex 10-H; US-Morocco FTA annex 10-D; US-Singapore FTA Side Letter (May 6, 2003); US-Oman FTA annex 10-D; US-Colombia Trade Promotion Agreement annex 10-D; US-Panama FTA annex 10-D; US-Peru Trade Promotion Agreement annex 10-D; US- 
particular, the Dominican Republic-Central America-US FTA requires that within three months of the date of entry into force of this Agreement, a Negotiating Group should be established to develop an appellate body or similar mechanism to review arbitral awards. ${ }^{158}$

Such an approach analogous to national judicial review has been considered by the International Center for Settlement of Investment Disputes ("ICSID") Secretariat. In 2004, the Secretariat proposed to establish an appellate system within the ICSID arbitration mechanism. ${ }^{159}$ In 2005, the Secretariat appeared to prefer a multilateral appellate mechanism rather than a separate one. However, it was considered too early to introduce the appellate mechanism because of "technical and policy issues." ${ }^{60}$ The important point is that, in the opinion of the Secretariat, it is still necessary to establish an appellate system. ${ }^{161}$ The ICSID Secretariat's shift to support a multilateral appellate mechanism has been accepted in the 2012 US Model BIT; ${ }^{162}$ the approach of 'separate' appellate mechanism has been abandoned.

Pursuant to the leaked negotiation text of Investment Chapter, TPP negotiating parties follow the new position of the 2012 US Model BIT. ${ }^{163}$ However, TPP negotiating parties have misunderstood the nature of the current negotiations; unlike a BIT which is applicable to two Contracting Parties only, TPP negotiations have involved eleven States with more who are expected to join. Therefore, it is an appropriate time to consider an appellate mechanism for reviewing arbitral awards and to realize the policy goal enshrined in the 2002 BTPA $^{164}$ and a number of investment treaties the US has signed. ${ }^{165}$

Uruguay BIT annex E.a

158 Dominican Republic-Central America-US FTA annex 10-F(1).

159 See Possible Improvements of the Framework for ICSID Arbitration, ICSID Secretariat Discussion Paper (Oct. 22, 2004), at 14, available at https://icsid.worldbank.org/ICSID/FrontServlet?requestType=ICSIDPublicationsRH\&actio $\mathrm{nVal}=$ ViewAnnouncePDF\&AnnouncementType=archive\&AnnounceNo=14_1.pdf (last visited on Sept. 9, 2013).

160 See Suggested Changes to the ICSID Rules and Regulations, Working Paper of the ICSID Secretariat (May 12, 2005), at 4, available at https://icsid.worldbank.org/ICSID/FrontServlet?requestType=ICSIDPublicationsRH\&action Val=ViewAnnouncePDF\&AnnouncementType=archive\&AnnounceNo=22_1.pdf (last visited on Sept. 9, 2013).

161 Id.

1622012 US Model BIT, art. 28 (10).

163 Investment Chapter (leaked) of TPP negotiations art. 12.22.10.

164 Supra note 127.

165 Supra note 157. 


\section{Conclusion}

The UNCTAD observed that negotiations on BITs "are losing momentum" and regional treaty-making "is gradually moving to center stage," which, it predicted, would "represent a step towards multilateralism." 166 TPP negotiations might support this presumption in the near future. Given the diversity of States involved and the comprehensiveness of coverage and the depth of commitments, TPP negotiations, although they are being conducted at a regional level, may have profound multilateral implications and offer a new hope for multilateral investment governance in the wake of MAI failures within OECD and the stagnation of investment rule-making agenda within WTO. Due to the determination of great powers, especially the US, and the effective negotiation strategies, TPP negotiations including an Investment Chapter are expected to be successfully concluded. In order to make the TPP investment regime contribute as much as possible to a more equitable, balanced and predictable investment regime as a whole, more initiatives deserve consideration, which include the inclusion of a new principle of S \& D treatment, incorporation of operative provisions of investment promotion, a Side Agreement on the code of conduct of transnational corporations, and an appellate mechanism for reviewing the arbitral decisions. 
